\title{
Ampulla of Vater Cancer Pathologic Regional Lymph Nodes TNM Finding v7
}

National Cancer Institute

\section{Source}

National Cancer Institute. Ampulla of Vater Cancer Pathologic Regional Lymph Nodes

TNM Finding v7. NCI Thesaurus. Code C90274.

A pathologic finding about one or more characteristics of ampulla of Vater cancer,

following the rules of the TNM AJCC V7 classification system as they pertain to staging of regional lymph nodes. 